\title{
IDENTIFICATION OF PRIVATISED PUBLIC UTILITIES AND RESIDENTIAL PROPERTIES IN IBEJU-LEKKI AXIS OF LAGOS STATE
}

\author{
Mujidat Iyabo Adedigba \\ Department of Estate Management \\ Oduduwa University Ipetumodu, Nigeria \\ E-mail: iyaboadedigba@gmail.com \\ Olugbenga Theophilus Babatunde \\ Department of Estate Management \\ Obafemi Awolowo University, Ile-Ife, Nigeria \\ E-mail: theobaba2013@gmail.com
}

\begin{abstract}
This study identified the different public utilities that are Privatised and the types of residential properties in Ibeju-Lekki in Lagos State. The area of study was stratified into high, middle, and low densities in the study area. From the records at Ibeju-Lekki government administrative office, it was further revealed that there were 56, 60, and 40 residential areas respectively on the high, medium, and low densities. Systematic random sampling selection without replacement was employed to select one of every four identified residential areas in each density, gives 14, 15, and 9 residential areas from the high, medium, and low densities respectively. There were 3,411, 1745, and 549 residential buildings in the identified residential areas. Selection of the first building in each area was done randomly while a subsequent unit of the investigation was every $20^{\text {th }}$ building which gave a sample size of 171, 87, and 27 residential buildings in the high, medium, and low densities respectively. One household head was selected in each building randomly. Data collected from household heads include information on the functional public utilities that are Privatised, types of buildings/ properties, the rental value of properties in the area from 2003-2015 among others. The result showed that there were six public utilities that are Privatised in the study area namely waste disposal, water supply, streetlight, road network, telecommunications, and postal service with variation in their functionality index across the densities. Finally, it was revealed that major types of residential properties identified in IbejuLekki axis of Lagos State were tenement, self-contained, bungalow, the block of flats, duplex, detached and semi-detached. The household heads need to be well informed on the need for privatization of public utility to enhance the participation of household heads in the decisionmaking process.
\end{abstract}

Keywords: Privatisation, Public Utilities, Residential Properties.

\section{INTRODUCTION}

Public utility according to Ariyo and Jerome (2004) referred to basic inputs required for the effective functioning of the economy with the motive to improve the standard of living of 
citizens. Public utility is also described as a cord that links people, social institutions, socioeconomic activities, and the natural environment into a coherent relationship (Otegbulu, 2014). Famuyiwa and Otegbulu (2012) defined public utility as a lubricant in the wheels of national development and paramount to nations' public welfare and development.

A public utility is to be an essential economic requirement for the development of production activities from the primary stage to the second stage and finally to the tertiary stage till it gets to the consumer. Examples of public utilities are water supply, telecommunication services, electric generation, distribution and consumption, waste management, among others. Public utility is traditionally financed by the government, monopolistic in nature, fixed to a particular location, and capital intensive. According to Jacobson and Tarr (1999), public utilities are structures and networks that surround and link urban areas, underpin social and economic activities. Public utilities serve multi-dimensional purposes and enhance improvement in the environment Otegbulu (2010). Utility naturally creates a service at a particular location and then distribute it over a network where it's allotted to interested customers for use.

The public utility was grouped into two social and economic (Parker, 2008). Social utility is referred to as social overhead capital by development economists. It is the focal point of all activities of the family, community, economic and industrial growth and development. These utilities directly or indirectly impact the quality of living. Directly, it improves the production process, social utilities are fundamental to production processes. Social utilities are about characteristics of social organization such as trust, norms, and networks that enhance efficiency. Social public utilities include services such as educational institution, public health facilities, correctional facilities, and welfare generated public utilities (Udo \& Egbenta, 2007), while economic public utilities are internal assets of a country that support commerce activities in the country.

Privatization of essential public utilities has been the trend in developing countries of the World (Tajudeen, 2004). Defined Privatisation as an effort to relieve the disincentives towards efficiency in public sector utilities by subjecting them to activities of the market. The Second National Economic Summit held in 1985 at Abuja according to the author defined privatization as a variety of policies aimed at transferring, fully, or partially ownership and control of public utility to the private sector to motive and encourage competition and emphasis activities of market forces in place of statutory legislation and monopoly power.

Economic public utilities are a basic requirement for the economic development of any nation. It does not necessarily produce goods and services but enhances production activities at both primary and secondary stages of production. These comprise utilities such as toll road, airport service, electric and water generation, distribution, and transmission among others. Huang (2006) classified public utility into Hard and Soft Public Utilities. The author also defined soft utilities as are country's legal regulatory and financial systems.

Ariyo and Jerome (2004) poised that the information, technology, and mode of governance of a country are examples of soft infrastructure in an economy, soft public utilities are intangibles, non-visible utilities the contribute to the gross domestic progress of an economy. Soft public utilities are difficult to measure their main impact is to improve investment decisions and improve individual work performance. Hard public utilities are visible, physical, and tangible public utilities of a nation of examples include airports, road networks, and communication facilities among others. Both hard and soft utilities are basic needs for economic growth. These public utilities are electricity, water supply road network, communication services waste collection, disposal, and management. 
Olaleye (2011) revealed that in a situation where there is an adequate, efficient, and functional public utility, residents are opened to many opportunities from ease in daily living to efficient, functional lifestyle and improved investment opportunities in residential property. Studies on privatisation of public utilities in Nigeria have chiefly concentrated on the nations' economic growth and development. Researches on the impact of privatization of public utilities on residential property value are still very scanty. This study, therefore, seeks to examine the impact of privatization on residential property value using Ibeju- Lekki area of Lagos State as case study.

Provisions of adequate public utility challenges include inadequate funds, lack of transparency, and political interferences from politicians among others. All these problems influence residential rental value. Studies on factors influencing residential property value include; Famuyiwa and Babawale (2012), and Adegoke (2014) these studies focused on internal and external factors influencing residential rental value. The work of Bello and Bello (2008) examined the willingness of residents to pay for better environmental public utilities at Akure, and found that income level, availability of dumpsite, and stable electricity were factors influencing household willingness to pay for additional improvement in the environment. This study identified the different public utilities that are Privatised and the types of residential properties in Ibeju-Lekki in Lagos State. On this note, this study aims to identify the different public utilities that are Privatised and the types of residential properties in Ibeju-Lekki in Lagos State.

\section{METHODOLOGY}

Primary and secondary data were employed to achieve descriptive statistics. The population entails Valuation firms, Estate surveying and Household heads in the study area. Questionnaire instrument was employed to elicit primary data. Apart from the population categories, the estate surveying and valuation firms were organized into professional bodies known as the Nigerian Institution of Estate Surveyors and Valuers (NIESV). Consequently, this allows for ease of questionnaire administration.

The other targeted population for the study was the household heads of identified residential densities (high, medium, and low) in the study area. The house heads were targeted population because they bear the cost of the comfort for the family and the burdens of paying for public utilities that are Privatised were their responsibility.

\section{Sampling Frame}

As earlier stated, the study population for this research was a total of the 57 Estate Surveying firms at the Ibeju-Lekki Axis. A reference was made to the Directory of the registered estates and valuers 2015 issued by the Nigeria Institution of Estate Surveyors and Valuers (NIESV). The lists of estate firms that have property on the axis without corporate offices were included to make 57 Estate Firms.

\section{Estate Surveying Firms}

The study was based on the total enumeration of 57 estate surveying firms in the study area that were established before the privatization of public utility on the axis. 


\section{Household Heads}

Records at the Ibeju-Lekki Local Government office revealed that there were a total of 5,705 residential buildings on the axis; on the high density were 3,411 residential buildings, 1,745 residential buildings on the medium, and 549 residential buildings on the low density, $5 \%$ of the sample frame can be taken as the sample size. 5\% across the densities were 171, 87, and 27 residential buildings on the high, medium, and low densities.

\section{RESULTS}

Information gathered from the department that is concerned with valuation at the Ibeju--Lekki Local Government Area office revealed one hundred and fifty-three (153) residential areas of Ibeju-Lekki Axis of Lagos which comprises of high, medium, and low densities when stratified. On the high density, were 55 residential areas, the medium density was made of 59 residential areasand the low density comprised of 39 residential areas. This classification is based on income, neighborhood characteristics, rental and capital values of properties within an identified residential area in the study area. The classification of the residential area to density is of importance to draw inference on the impact of privatization of public utilities on identified residential areas in the study area for analysis of the research.

The residential areas were selected using a random selection of the fourth identified residential area from the selected density without replacement. Selected buildings were from the first building from the residential area while a subsequent unit of the investigation was every $20^{\text {th }}$ residential building in each area. Systematic sampling of buildings was questionnaire was administered to one household head was selected.

A total of thirty-eight residential area were selected in this study. The residential areas were grouped into high, medium and low densities. The high densities comprises of fourteen residential areas which are Fadunjoye, Dengo, Iba, Igor, Gogoro, Idiori, Ilumofin, Ise, Oke-Abe, Mosere -lkoga, Oke-egun, Dongo, Ebute-Lekki, Araromi. The medium densities comprises of fifteen residential areas which are Ajegbenwa, Alasiah, Ayeteju, Badore, Idaho, Mapo-Akinlade, Magun-Alade, Mapo-Ijebu, Ebute-Lekki, Iwerekun, Siriwon, Ilagbo-Itagbo, Ilege, Tiye, Ogogoro. The low densities comprises of nine residential areas which are Abijo, Awoyaya, Elepatu, Ekutu, Akodo, Lagasa, Lakowe, Igando, Palaver- Island.

Table 1. Residential Densities of the Study Area

\begin{tabular}{|l|l|l|l|l|}
\hline $\begin{array}{l}\text { Residential } \\
\text { Densities }\end{array}$ & $\begin{array}{l}\text { Number of } \begin{array}{l}\text { Selected } \\
\text { residentified } \\
\text { densities }\end{array} \\
\text { residential areas } \\
\mathbf{2 5 \% )}\end{array}$ & $\begin{array}{l}\text { Number of } \\
\text { buildings in the } \\
\text { selected residential } \\
\text { area }\end{array}$ & $\begin{array}{l}\text { Sample size } \\
\mathbf{5 \%}\end{array}$ \\
\hline High & 55 & 14 & 3411 & 171 \\
\hline Medium & 59 & 15 & 1745 & 87 \\
\hline Low & 39 & 9 & 549 & 27 \\
\hline Total & $\mathbf{1 5 3}$ & $\mathbf{3 8}$ & $\mathbf{5 7 0 5}$ & $\mathbf{2 8 5}$ \\
\hline
\end{tabular}

Source: Record at Ibeju-Lekki Local Government Area (2016)

Information on residential property transactions was obtained from 57 Estate Surveying and Valuation Firms operating within the study area. Records from the Ibeju-Lekki government 
office showed that there were 153 residential areas on the axis from which thirty - eight residential areas were selected for the study. The records futures revealed the number of residential buildings on the selected densities.

To examine the public utilities that are privatised in the study area, the household heads were provided with the option of twenty identified public utilities. Six public utilities that were privatized were considered in this study based on water supply, road network, telecommunications, street lighting, and waste disposal system.

Table 2. Functionality Index of Privatised Public Utilities in the High Density

\begin{tabular}{|l|l|l|l|}
\hline Privatised Public Utility & Functionality Index & Mean Deviation & Rank \\
\hline Water supply & 4.35 & 0.69 & $1^{\text {st }}$ \\
\hline Road Network & 3.98 & 0.32 & $2^{\text {nd }}$ \\
\hline Telecommunications & 3.85 & 0.19 & $3^{\text {rd }}$ \\
\hline Street lighting & 3.43 & -0.23 & $4^{\text {th }}$ \\
\hline Waste disposal & 3.42 & -0.24 & $5^{\text {th }}$ \\
\hline Postal services & 2.91 & -0.75 & $6^{\text {th }}$ \\
\hline
\end{tabular}

Source: Author's Field Survey (2017)

Based on the findings presented above, it was revealed that there is an agreement between the household heads that three public utilities that are privatised out of the six public utilities in the high-density area of Ibeju-Lekki positively influence property and rental value. Findings regarding the Medium density area are shown in Table 3.

Table 3. Functionality Index of Privatised Public Utilities in the Medium Density

\begin{tabular}{|l|l|l|l|}
\hline Privatised Public Utility & Functionality Index & Mean Deviation & Ranking \\
\hline Road Network & 4.01 & 0.43 & $1^{\text {st }}$ \\
\hline Water supply & 3.96 & 0.38 & $2^{\text {nd }}$ \\
\hline Waste disposal & 3.62 & 0.04 & $3^{\text {rd }}$ \\
\hline Telecommunications & 3.46 & -0.12 & $4^{\text {th }}$ \\
\hline Street lighting & 3.36 & -0.22 & $5^{\text {th }}$ \\
\hline Postal services & 3.09 & -0.49 & $6^{\text {th }}$ \\
\hline
\end{tabular}

Source: Author's Field Survey (2017)

Based on the findings presented above, it was revealed that there is an agreement between the household heads that three public utilities that are privatised out of the six public utilities in the medium-density area of Ibeju-Lekki positively influence property value. They also revealed that privatization had negative functionality index which implies that the variation in the impact of improvement in property value is brought by privatization, and it varies on location densities. Findings regarding the Low density area are shown in Table 4 
Table 4. Functionality Index of Privatised Public Utilities in the Low Density

\begin{tabular}{|l|l|l|l|}
\hline Privatised Public Utility & Functionality Index & Mean Deviation & Ranking \\
\hline Water supply & 4.30 & 0.43 & $1^{\text {st }}$ \\
\hline Road Network & 4.22 & 0.35 & $2^{\text {nd }}$ \\
\hline Waste disposal & 3.96 & 0.09 & $3^{\text {rd }}$ \\
\hline Street lighting & 3.74 & -0.13 & $4^{\text {th }}$ \\
\hline Telecommunications & 3.65 & -0.22 & $5^{\text {th }}$ \\
\hline Postal services & 3.35 & -0.52 & $6^{\text {th }}$ \\
\hline
\end{tabular}

Source: Author's Field Survey (2017)

Based on the findings, it was revealed that there is an agreement between the household heads that three public utilities that are privatised out of the six public utilities in the low-density area of Ibeju-Lekki positively influence rental value.

The ranking of the public utilities that are Privatised according to their functionality is presented in Table 5. Water supply, road network, telecommunication, waste disposal, street light, and postal services were ranked $1^{\text {st }}$ to $6^{\text {th }}$ respectively.

Table 5. Functionality Index of Privatised Public Utilities in the Study Area

\begin{tabular}{|l|l|l|l|}
\hline Privatised Public Utility & Functionality Index & Mean Deviation & Ranking \\
\hline Water supply & 4.2 & 0.55 & First \\
\hline Road Network & 4.02 & 0.37 & Second \\
\hline Telecommunications & 3.68 & 0.03 & Third \\
\hline Waste disposal & 3.55 & -0.10 & Fourth \\
\hline Street lighting & 3.44 & -0.21 & Fifth \\
\hline Postal services & 3.02 & -0.63 & Sixth \\
\hline
\end{tabular}

Source: Author's Field Survey (2017)

Based on the above findings, it was revealed that public utilities that are privatised on the three residential densities contribute effectively to the rental value on the axis. They contain street lights, and water supply, good roads, effective waste disposal system which enhances the rental value. Also, there are differences in the level of infrastructures that are made available in each of the densities; this is the socioeconomic characteristics of housing based on densities.

Concerning the types of residential properties on the axis, major types of residential properties identified from a review of literature were tenement, self-contained, bungalow, the block of flats, duplex, detached, semidetached, and bungalow. To achieve this objective, household heads were presented with a list of different house types in the questionnaire to indicate the type occupied. The result is presented as follows. 
Table 6. Types of Residential Properties in the Study Area

\begin{tabular}{|l|l|l|l|l|l|l|l|l|}
\hline \multirow{2}{*}{ Residential Properties Types } & \multicolumn{2}{l}{ High Density } & \multicolumn{2}{l|}{ Medium Density } & \multicolumn{2}{l|}{ Low Density } & \multicolumn{2}{l|}{ Total } \\
\cline { 2 - 9 } & Freq. & $\boldsymbol{\%}$ & Freq. & $\boldsymbol{\%}$ & Freq. & $\boldsymbol{\%}$ & Freq. & $\%$ \\
\hline Tenement & 34 & 16.1 & 19 & 9.0 & 0 & 0.0 & 53 & 25.1 \\
\hline Block of Flat & 28 & 13.3 & 30 & 14.2 & 9 & 4.3 & 67 & 31.8 \\
\hline Bungalow & 12 & 5.7 & 8 & 3.8 & 3 & 1.4 & 23 & 10.9 \\
\hline Self-contained & 25 & 11.8 & 9 & 4.3 & 10 & 4.7 & 44 & 20.9 \\
\hline Duplex & 4 & 1.9 & 7 & 3.3 & 1 & 0.5 & 12 & 5.7 \\
\hline Detached & 2 & 0.9 & 3 & 1.4 & 0 & 0.0 & 5 & 2.4 \\
\hline Semidetached & 6 & 2.8 & 1 & 0.5 & 0 & 0.0 & 7 & 3.3 \\
\hline
\end{tabular}

Source: Author's Field Survey (2017)

Findings on the building type in the High-density areas of Ibeju-Lekki as presented in Table 6 established the dominance of tenement buildings, a block of flats, and self-contained apartments which accounted for $16.1 \%, 13.3 \%$, and $11.8 \%$ respectively. However, in the medium density, Block of Flatsdominates with $14.2 \%$ followed by tenement building $9.0 \%$ among other housing types. The low density which is the high-income earners' area recorded the dominance of Duplex given at $4.7 \%$ and Bungalows at $4.3 \%$ among other housing types.

The implication of the findings is that in Ibeju-Lekki, the residential property type's ranges from tenement building, flat bungalows, self-contained, duplex detached, and semidetached. However, tenement building which is termed as a Brazilian building and self-contained apartment is peculiar to the high-density area and a few in the medium density areas, while flats are peculiar to medium density area and less in the high-density areas. The low-density area demonstrated its social status as bungalows and duplexes are much more dominant. This is an indication the residential properties vary in their housing typologies according to the densities. There were different types of buildings across the different densities with socioeconomic characteristics of different household heads influencing house types across the densities.

\section{CONCLUSION}

This study aimed at identifying different public utilities that are Privatised and the types of residential properties in Ibeju-Lekki in Lagos State. The area of study was stratified into high, middle, and low densities in the study area. From the records at Ibeju-Lekki government administrative office, it was further revealed that there were 56, 60, and 40 residential areas respectively on the high, medium, and low densities. Systematic random sampling selection without replacement was employed to select one of every four identified residential areas in each density, gives 14, 15, and 9 residential areas from the high, medium, and low densities respectively. There were $3,411,1745$, and 549 residential buildings in the identified residential areas.

Selection of the first building in each area was done randomly while a subsequent unit of the investigation was every $20^{\text {th }}$ building which gave a sample size of 171,87 , and 27 residential 
buildings in the high, medium, and low densities respectively. One household head was selected in each building randomly. Data collected from household heads include information on the functional public utilities that are Privatised, types of buildings/ properties, the rental value of properties in the area from 2003-2015 among others.

The result revealed that there were six public utilities that are Privatised in the study area namely waste disposal, water supply, streetlight, road network, telecommunications, and postal service with variation in their functionality index across the densities. Finally, it was revealed that major types of residential properties identified in Ibeju-Lekki axis of Lagos State were tenement, self-contained, bungalow, the block of flats, duplex, detached and semi-detached. The household heads need to be well informed on the need for privatization of public utility to enhance the participation of household heads in the decision-making process.

\section{REFERENCES}

Adegoke, O. J. (2014). Critical Factors Determining Property Value of Residential Property in Ibadan Metropolis, Nigeria Property Management, Emerald Group Publishing Limited, $32(3), 224-240$.

Ariyo, A., \& Jeromn, A. (2004). Privatisation and the Poor in Nigeria in Focus. World Development, 27(7), $201-213$.

Bello, M. O., \& Bello, V.A. (2008). Willingness to Pay for Better Environmental Services: Evidence from the Nigeria Real Estate Market. Journal of Africa Real Estate Research, 1(1), 19-27

Famuyiwa, F. \& Otegbulu, A. C. (2012). The Influence of Water Infrastructure on Rental Values: Hedonic model, Elixir Infrastructure Management, 51(8), 11034-11038.

Huang, Y. (2006). Paper prepared for the Carnegie Endowment Conference Beijing, China.

Jacobson, C. D., \& Tarr, J. A. (1999). Ownership and financing of infrastructure: Historical perspectives. The World Bank.

Olaleye, A. (2011). Globalization and the Future of property Investment in Nigeria, Journal of The Estate Surveyor and Valuer, 35(1), 145 - 156

Otegbulu, A. C. (2014). Urban Infrastructure Condition and Neighbourhood Sustainability: A Contingent Valuation. Ethiopian Journal of Environmental Studies \& Management, 7 (2), 160- 170

Otegbulu, A. C. (2010). User Preference in Urban Infrastructure Provision Using the Contingent Valuation Model, Thesis at Enugu State University of Science and Technology, Enugu, Nigeria.

Parker, G. (2008). Investing in Asian infrastructure: The S\&P Asia infrastructure index. Available at SSRN 1321723. 
Tajudeen, A. B. (2004). Privatization of public enterprises in Nigeria: Valuation issues and problems. Journal of Business Economics and Management, 5(4), 193-203.

Udo, G. O., \& Egbenta, I. R. (2007). Effect of domestic waste dumpsites on rental values of residential properties in Enugu. The Nigerian Journal of Development Studies, 6(1), 7998.

\section{Copyrights}

Copyright for this article is retained by the author(s), with first publication rights granted to the journal. This is an open-access article distributed under the terms and conditions of the Creative Commons Attribution license (http://creativecommons.org/licenses/by/4.0/). 